\title{
データ統合活用による \\ 夏季インドモンスーン形成過程の研究 \\ A PROCESS STUDY OF THE ONSET OF THE INDIAN SUMMER MONSOON BY USING DATA INTEGRATION
}

\author{
谷口健司 1 - 小池俊雄 $2 \cdot$ 生駒栄司 ${ }^{3} \cdot$ 喜連川優 4 \\ Kenji TANIGUCHI, Toshio KOIKE, Eiji IKOMA and Masaru KITSUREGAWA \\ 1学生会員 工修 東京大学大学院工学系研究科 博士課程 ( $\mathrm{T} 113-8656$ 東京都文京区本郷七丁目3-1) \\ 2正会員 工博 東京大学大学院工学系研究科 教授（１13-8656 東京都文京区本郷七丁目3-1) \\ 3 非会員 工博 東京大学空間情報科学研究センター 助手 ( ₹ 153-8904 東京都目黒区駒場四丁目6-1) \\ 4非会員 工博 東京大学生産技術研究所 教授 （厂153-8505 東京都目黒区駒場四丁目6-1）
}

\begin{abstract}
The formation of the strong westerly over the Arabian Sea, which is characterized as the onset of the Indian summer monsoon provides the monsoon rainfall in India. By integrating the data sets of precipitation, outgoing long-wave radiation, cloud amount and sea surface temperature, the seasonal march of the atmospheric and earth surface conditions are examined. Based on the detail investigation of the case of 1999 and 2001, two patterns of process of the monsoon onset are identified; one associated with a cyclone event and the other with the southwest advection into the Arabian Sea but not any cyclone. For the latter cases, this paper shows that a monsoon onset is controlled by the potential temperature gradient between the Arabian Peninsula and the Arabian Sea, and between the Iran-Pakistan region and the Arabian Sea.
\end{abstract}

Key Words : Indian summer monsoon, Asian summer monsoon, interannual variability, data integration

\section{1. はじめに}

近年注目されつつある様々な水危機問題の解決のため には，安定で効果的な水資源計画の実現が必要である。 そのためには, 中長期的な気候変動予測及び短期の気象 予報においてもより高い精度が不可欠である1). また， アジア域においては夏季アジアモンスーンが社会・経済 に大きな影響を与えるが，その季節進行あるいは年々変 動の物理過程の大部分は明らかではない. 夏季インドモ ンスーンに関しては, 早くから, インド洋およびアラビ ア海上を通りインド亜大陸に吹き込む強い西風によって, インド亜大陸に水蒸気が運ばれ，降水がもたらされると 考えられてきた. しかし，この強い西風の形成過程に関 する詳細な理解は未だなされていない.

一方で, 近年の観測技術の向上に伴い, 様々な種類の 有用な地球環境デー夕が提供されるようになってきた。 本研究では, これら多くの有用なデー夕を充分に活用し
ながら，先に述ベたインドモンスーン開始期に着目して その形成過程の記述を行った。

\section{2. データ統合活用}

(1) データ

本研究では, 夏季インドモンスーンの開始にあたる風 系の形成に至る大気場の季節進行を詳細に追うために 様々なデータを用いている.

夏季モンスーン期間における降水分布と季節变化をみ るために全球降水気候計画 (Global Precipitation Climatology Project : GPCP) のデータを用いた. GPCP では衛星搭載の赤外およびマイクロ波放射計等によって 算定された降水デー夕と現地観測による降雨量データと. を合わせて作成した全球降水デー夕を提供している。 1979年から現在に至るまでの月平均降水量と，1997年か ら現在までの日平均降水量が入手可能である. また, 熱 
帯域における対流活動の指標として外向き長波放射

(Outgoing Long-wave Radiation : OLR) も夏季モンスー ンの記述に関して有用である ${ }^{2)}$. 米国大気海洋庁

( National Oceanic and Atmospheric Administrator : NOAA）では1975年から現在に至るまでのOLRデータが 提供されている3). 日単位の季節変化を詳細に調べるた めにこれらのデータを用いることとした。なお，空間解 像度はGPCP降水データが1度×1度, NOAA OLRデータ が2.5度×2.5度である。

風速, ジオポテンシャル高度, 大気温度といった大 気データに関してはNational Center for Environmental Prediction/National Center for Atmospheric Research (NCEP (NCAR)の再解析データ)を用いた。これらは空間解像度 が2.5度 $\times 2.5$ 度の日平均データである.

雲の季節变化には国際衛星雲気候計画 (International Satellite Cloud Climatology Project : ISCCP) のデータ5)を 用いた，時間解像度は3時間であり，日平均OLRデー夕 でははっきりと示されない雲の存在をみることも可能で ある。空間解像度は 2.5 度 $\times 2.5$ 度である。

海面水温は熱帯降雨観測衛星（Tropical Rainfall Measuring Mission：TRMM）搭載のマイクロ波放射計

（TRMM Microwave Imager：TMI）による観測デー夕を 用いた．空間解像度は 0.25 度 $\times 0.25$ 度であり, 3 日平均值 が1997年12月からの各日に対して提供されている。

\section{（2）データ統合活用}

衛星観測技術の発達に伴い, 雲水量, 海面水温, 降水, 積雪など多くの地球環境デー夕が高時間解像度・高空間 分解能で得られるようになっている。また，NCEP NCAR再解析デー夕等の長期にわたる客観解析データが 整備されてきている。これらのデー夕は年間数十テラバ イトにも上る．膨大なデータから現象理解につながる知 見を効率的に得るためには，従来気象学において行われ てきた以上の統合利用を実現する必要があり，自然科学 分野と情報学分野の融合が不可欠である．統合強化観測 期間（Coordinated Enhanced Observing Period : CEOP）で は，現地観測デー夕，衛星観測デー夕，数值モデルの出 力を収集, 保存し, 時空間解像度の異なるデー夕を統合 活用する研究を行い，両者の協力の下，高次の情報抽出 を目指した研究環境の構築，解析手法の開発を行ってい る.このための大きな課題のひとつは, 膨大なデー夕の 使用と処理である．年間数十テラバイトに上るデータの 蓄積は個人の計算機環境に収まるものではない。また， 膨大なデー夕は利用されてこそ価値のあるものであり， 広く利用が可能な環境の構築が望ましい.こうした要求 から，デー夕処理はウェブブラウザを介しリモートサー バで行われ，全デー夕処理が終了すると，電子メールに よって解析結果を公開したURLが通知されるよう設計さ れた．たとえば，全球デー夕に対する相関係数の計算時 間は，対象となるデー夕の種類，期間が長期化するとと (a) THETA(K)\&Z\&U 21MAR $850 \mathrm{hPa}$

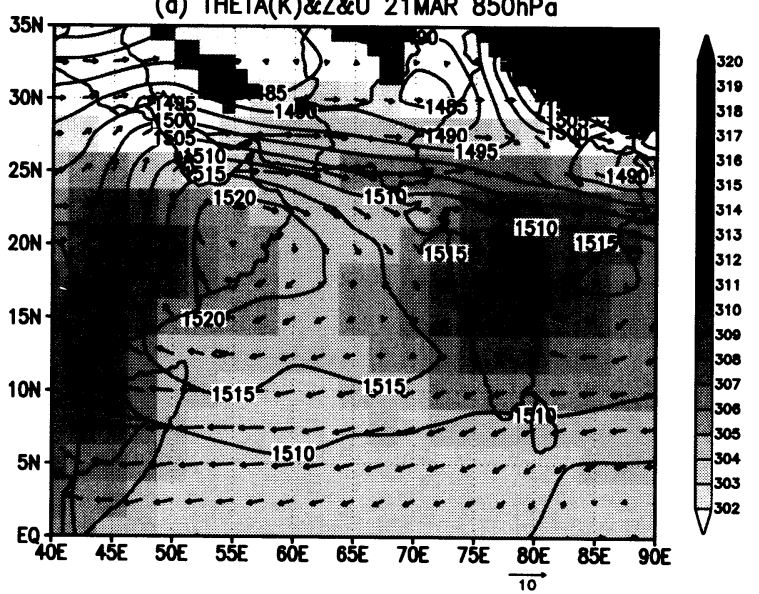

(b) THETA(K)\&Z\&\&U 20JUL $850 \mathrm{hPa}$

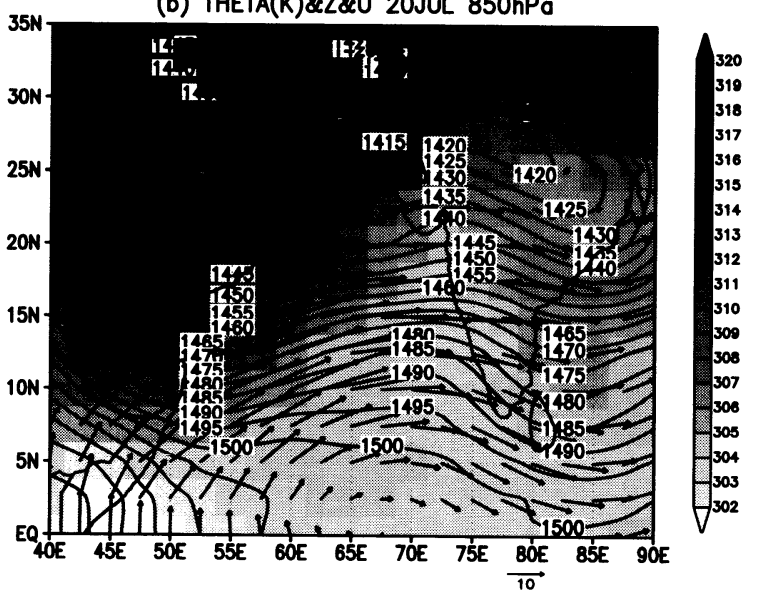

図-1 NCEP/NCAR再解析デー夕気候值による850hPa温位,

風系, ジオポテンシャル高度. (a) インドモンスーン 開始以前，（b）インドモンスーン成熟期．等值線が ジオポテンシャル高度 $(\mathrm{m})$ である.

もに急激に増加する，格納すべきデー夕量からも高い計 算機能力が必要とされ, 膨大なデー夕の高速処理を行う には市販のパーソナルコンピュータでは追いつかない部 分も大きい. そうした意味でも，こうしたシステムを ネットワークを介して利用できる環境の構築は重要であ る.また，解析結果の可視化及び閲覧は無料で配付され ているソフトウェアで可能である.

本研究はそのような研究の一環として, 多様なデー夕 を用いてひとつの現象解明に取り組んだものでもある.

\section{3. 事例解析}

（1）インドモンスーン

インドモンスーンの開始前後には明確な場の変化が生 じる．図-1aはモンスーン開始以前の850hPaにおける温 位, 風系, ジオポテンシャル高度の分布である。 なお, NCEP/NCAR再解析デー夕による気候値を用いた。一方, 図-1bはインドモンスーン開始直後の大気場の様子であ る.図-1aではアラビア海の温位は周囲の陸域よりも低 
(o) THETA(K)\&Z\&U 14MAY1999 850hPo

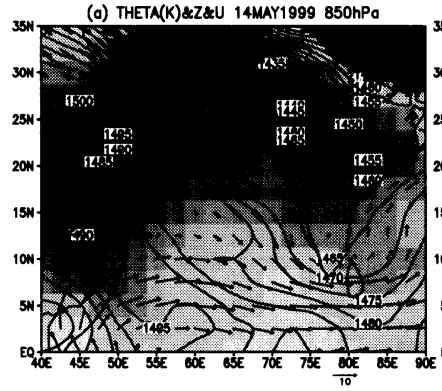

(b) THETA(K)\&Z\&U 17MAY1999 850hPo

(c) THETA(K)\&Z\&U 19MAY1999 $850 \mathrm{hPo}$

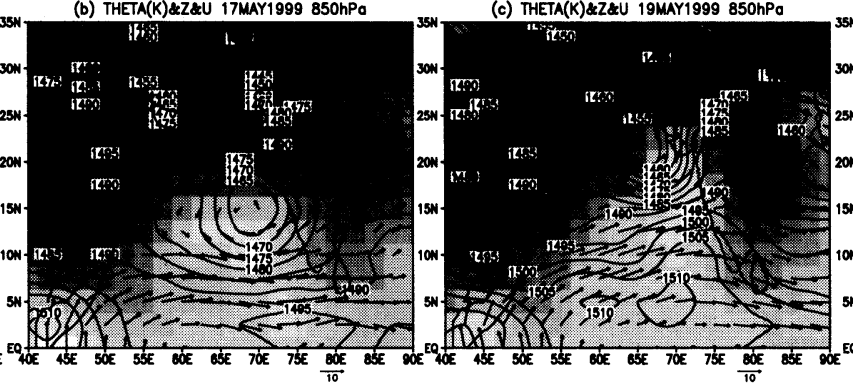

(d) THETA(K)\&Z\&U 22MAY1999 850hPo

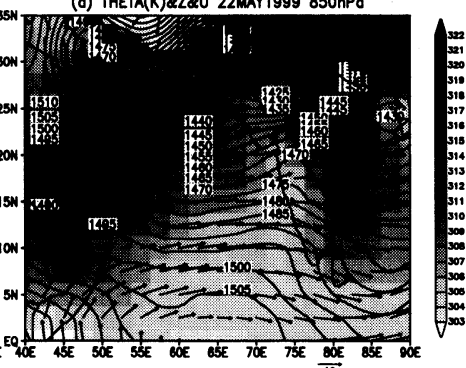

図-2 1999年における大気場の様子.
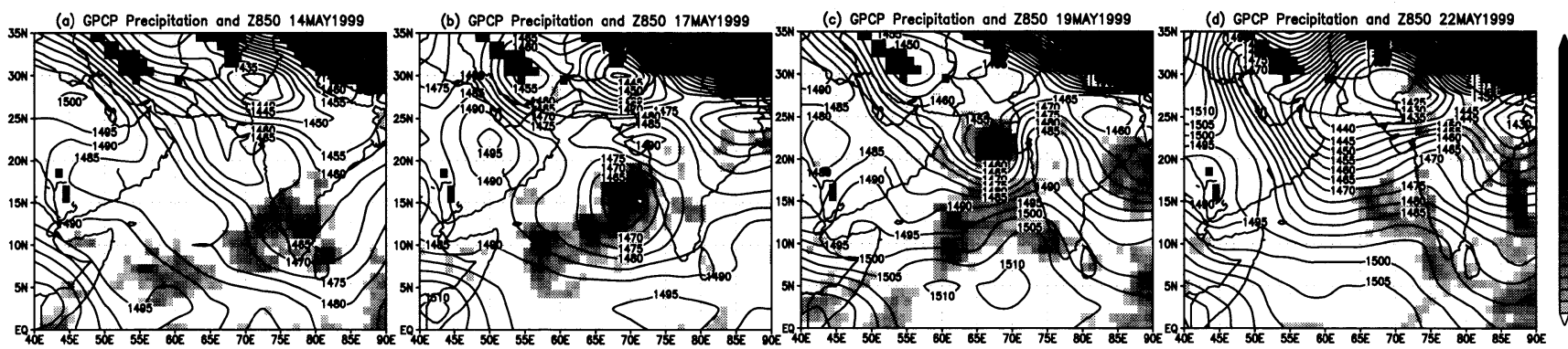

図-3 1999年のGPCP日平均降水量 (mm/日) と NCEP/NCAR再解析データの850hPaジオポテンシャル高度.

くアラビア半島からアラビア海にかけては高圧性循環場 が存在している。この高圧性循環は，この領域が亜熱帯 高圧帯に位置していることによって形成されるものと考 えられる。一方, 図-1bではアラビア海からインド亜大 陸にかけて，等ジオポテンシャル高度線に沿って強い西 風か吹き抜けており，これによってインド洋からアラビ ア海上の水蒸気がインド亜大陸に運ばれ，降水をもたら す。この強い西風の形成は夏季インドモンスーンの開始 と同等のものといえる. 温位の分布はアラビア半島から イラン，パキスタンといった陸域で高く，アラビア海や インド洋，そしてインド亜大陸西岸に低温位域が位置し ている。このような温位分布がモンスーンの西風を吹か せる気圧傾度を形成するのに不可欠と考えられる。

図-1aから図-1bに至る過程が夏季インドモンスーン形 成までの季節進行である.この季節進行の詳細な事例解 析を行った結果を次に示す.

（2）1999年：サイクロンによる西風の形成

a）5月14日 : アラビア半島上の高圧性循環の弱まり

図-2aは1999年5月14日の大気場の様子である.インド 亜大陸とイランーパキスタン領域上の大気は加熱してお り，アラビア海北部には陸域から北西風か吹き込んでい る.これによって陸域の暖かな空気がアラビア海上に運 ばれることによって，同海上の温位が上昇している。ア ラビア半島上の温位も上昇し, 同領域の高圧性循環場が 弱まっている．北緯5度から10度においては西風が吹い ているが，先に述べた北西風によって，アラビア海への 吹き込みは妨げられている.

一方，図-3aは同日のGPCPの日平均降水量㧍よびジオ ポテンシャル高度の分布であり, インド覀大陸南端に弱 い降水域が見られる。

\section{b）5月17日：サイクロンの発生}

アラビア海東部に降水域が発達しサイクロンが形成さ れ，北上を始める（図-3b）。アラビア海およびインド 南端付近の温位はやや低下寸るが，図-1bにみられたモ ンスーンの西風を吹かせるような大きな温度傾度を形成 されるほどのものではない (図-2b) .

c）5月19日 : アラビア海東部の温位の低下

北上したサイクロンは非常に強い降水を伴ってアラビ ア海北端に達する．図-2cでは，アラビア海東部の温位 が低下しているのが認められ，北緯5度から10度に吹く 西風はサイクロン周辺の循環場を強化し，アラビア海お よびインド亜大陸へ南西風が吹込むようになる。

d）5月22日：インドモンスーンの開始

サイクロンは消滅し, 降水も弱まる。.アラビア海東部 およびインド亜大陸西岸の温位は低いままとなっている。 アラビア半島の温位は夏季インドモンスーンの成熟期に おけるほど高くはなっていないが，陸域と海域との温度 傾度は大きくなっており，モンスーンの西風を吹かせる。

みてきたように，1999年5月14日はモンスーンの西風 を形成するに十分な大気状態ではないが，サイクロンに よって温位の低下がもたらされ南西風が強化されるよう になり，やがてモンスーンの西風を形成する.

（3）2001年：サイクロンによらない西風の形成

(2)では1999年にサイクロンの通過に伴うアラビア海 東部の温位低下による西風の形成を季節変化とともにみ ていった。ここではサイクロンの通過といったイベント を伴わない場合の季節進行について述べる.

a）4月22日：モンスーン形成前の状態

図-4aは2001年4月22日の大気状態である。モンスーン の西風形成過程の始まる以前の状態であり, アラビア海 

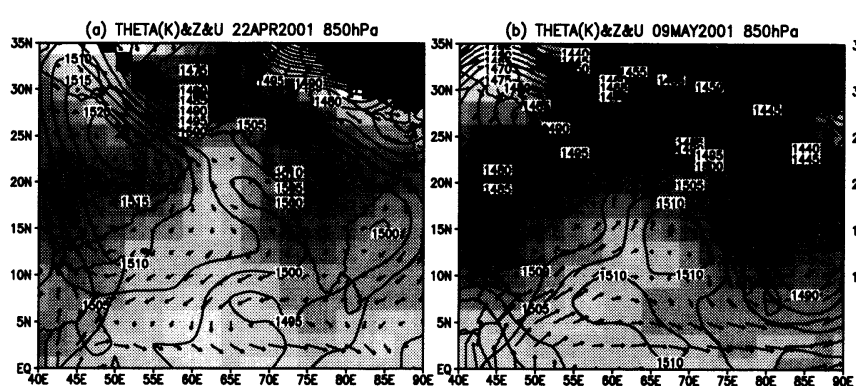

(e) THETA(K)\&Z\&U 08MAY2001 850hP

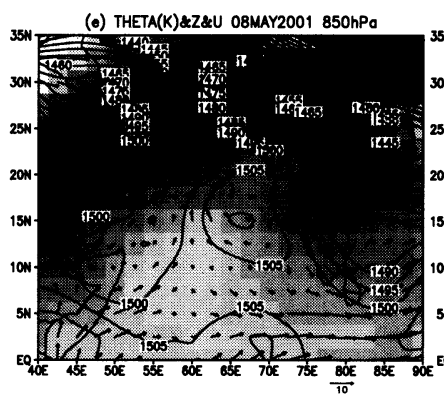

(f) THETA(K)\&Z\&U O9MAY2001 850hPa

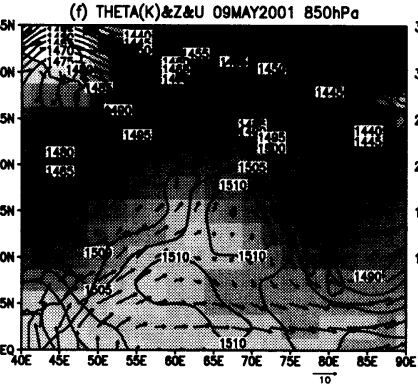

図-4 2001年の850hPa大気場の季節進行.
北部周辺において陸域の温位のほうが海洋上より高い. 等ジオポテンシャル線および風系に着目すると, アラビ ア半島上には高圧性の時計回りの循環場が存在している. b）4月29日：アラビア海の温位上昇

陸域の加熱が進む. インド亜大陸およびイランーパキ スタン領域の加熱も進行し，その領域の気圧が低くなる。 これによってイランーパキスタン域では低圧場の等高線 に沿った西風か吹き，インド亜大陸では熱的低気圧のよ うな状態が形成されインド西岸に沿った北風が形成され る.アラビア半島からアラビア海に広がっていた高圧場 は弱まっている.

アラビア海では北部の温位が上昇する，これは，陸域 の暖まった空気塊がイランーパキスタン域の西風やイン ド西岸の北風によって海洋上に運ばれ，気温が高くなっ ているためと考えられる.

\section{c）5月2日：高圧性循環の影響}

4 月29日に弱くなっていたアラビア半島からアラビア 海にかけての高圧性循環場が再び強くなる。この高圧性 循環の東側の北風成分によって陸域の暖かな空気が海洋 上に運ばれ，アラビア海の温位はさらに上昇する。

\section{d）5月6日 : アラビア半島上の高圧性循環の弱まり}

アラビア半島からアラビア海に広がっていた高圧性循 環が弱まっている. また, アラビア半島とインド洋北部 周辺域との間の温度傾度によって, アフリカ東部に南西 風が形成されアラビア海へ吹き込む風系ができる.

e）5月8日：アラビア海西部の温位低下

アフリカ東部からアラビア海北端に至る弱い南西風が 形成されている。これによって海洋上の冷たい空気塊が 北へと運ばれ，アラビア海西部では温位の低下がみられ る.アラビア海東部ではインド西岸に沿う北からの風が 残っているため, そちらからの暖かな空気塊が温位を高 いままに維持している. (c) THETA(K)\&Z\&U 02MAY2001 850hPo

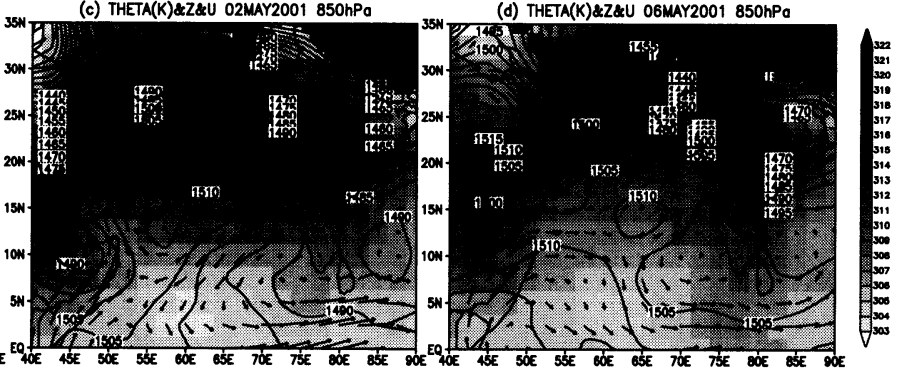

(h) THETA(K)\&Z\&U 18MAY2001 850hPo
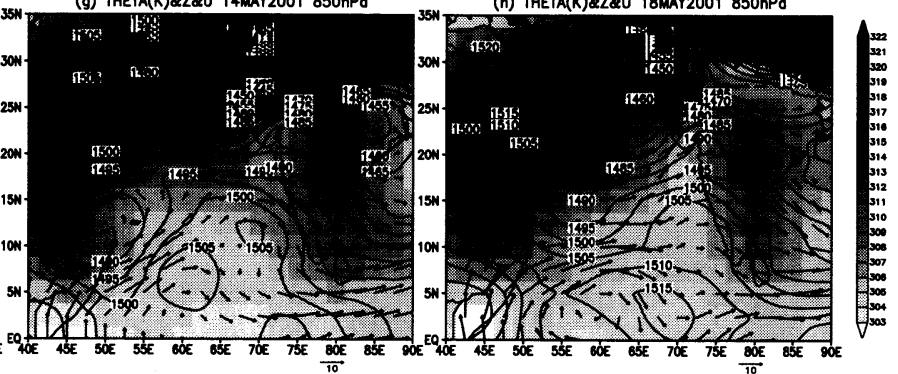

\section{f）5月9日 : 南西風の強化}

アフリカ東部からアラビア海へ吹き込む南西風が強く なる. 北緯5度から 10 度付近の西風も強まっている. 南 西風の強化とアラビア海上の温位の低下によって, 海洋 上の暖かくない空気がさらに北東方向へと広がっている.

\section{g）5月14日：低温位域の拡大}

陸域の加熱が進み, 温度傾度が大きくなることによっ て, 南西風がさらに強化しアラビア海に温位の低い領域 が拡大する．アラビア海だけではなくインド西岸の温位 も低下し, 弱い西風がインド亜大陸に吹き込み始める.

h）5月18日：モンスーンの西風の形成

アラビア半島やイランといった陸域の温位がさらに上 昇することによって, 図-1bのような温位分布となる。 これによってアラビア海全域に強い南西風あるいは西風 が形成されインド亜大陸に吹き込みを開始する。

2001年の西風形成までの過程はサイクロンの突発的 な大気場の変化が生じるというものではなかった. この 場合，はじめ小さな温度傾度によって形成された南西風 によってアラビア海に温位の低い領域が広がり，陸域の 加熱と相まってさらに温度傾度が大きくなり南西風が強 まり，温位の低い領域が広がるというフィードバックに よって徐々にモンスーンの西風が形成されるというもの であるということができる.

\section{（4）海面水温の影響}

本節の(2)および(3)では温位の変化はサイクロンや水 平移流によってもたらされると説明した. しかし海洋上 では, 海面水温 (Sea Surface Temperature：SST) の変化 が大気海洋相互作用を通じて大気場の状態に影響を与え る可能性がある.

図-5は1999年5月1日の大気場の様子とTMIによるSST の分布を比較したものである.これはアラビア海の温位 
(a) THETA(K)\&Z\&U 01MAY1999 850hPa

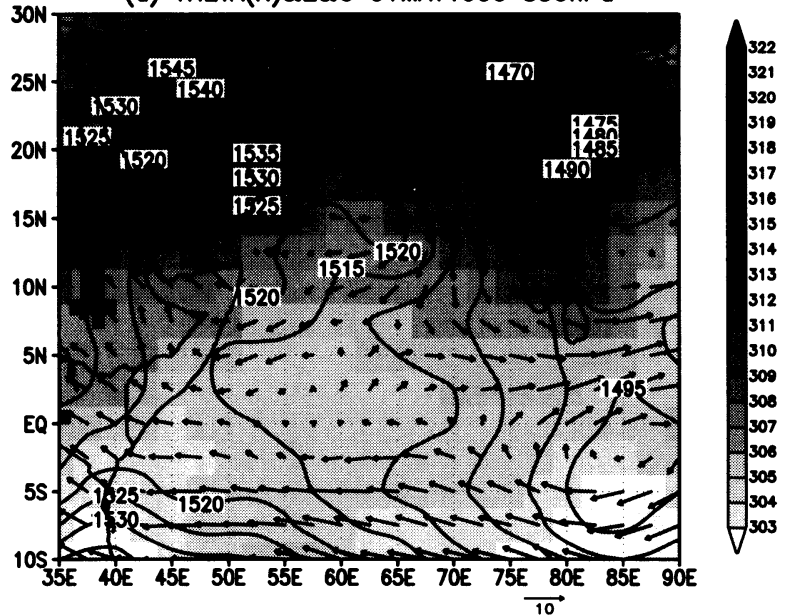

(b) TMI SST(degreeC) 01MAY1999

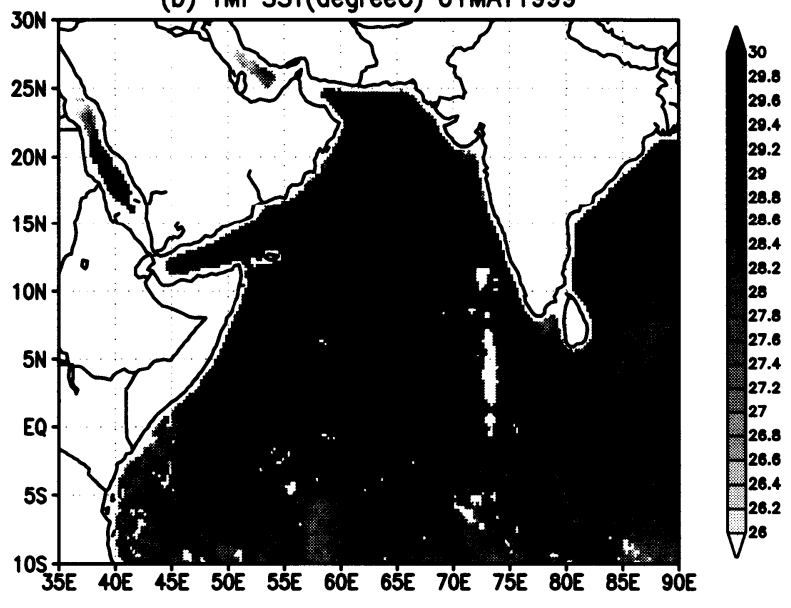

図-5 温位分布と海面温度分布の比較. (a) 1999年5月1

日の大気状態（b）同日の海面温度.

が上昇した時期にあたるものである（図一 $4 a$ から図-4cへ と大気の状態が変化したものと同等）。 $850 \mathrm{hPa}$ 温位はア ラビア海南部よりも北部のほうが高い.アラビア海上の 風系はイランーパキスタン域とインド覀大陸の加熱によ る北西風と高圧性循環による北風がみられる. SSTの分 布はアラビア海北部のほうが南部におけるよりも高く, $850 \mathrm{hPa}$ の温位分布と対応していない.これらの結果より， 北西風による陸域の暖かな空気塊のアラビア海への流入 で温位が上昇していると考えられる．850hPaの温位がア ラビア海北部で高く, 南部で低く，またSSTは逆の分布 となっているというこうした特徵は毎年認められる.

1998年のインド洋およびアラビア海のSSTは非常に高 く, 850hPa温位も例年に比べて高かった。この年はイン ド亜大陸の南西で発生したサイクロンによってアラビア 海東部の温位が低下しインドモンスーンの西風が形成さ れたが，サイクロンが生じていなければアラビア海の温 位低下は例年より遅れ，インドモンスーンの開始も遅れ ていた可能性もある。このようにSSTはその年の基本的 な大気状態を支配する可能性があるが，日単位の変化の ような短期間の大気場の変化には大きな影響を与えない と考えられる。
表-1 各年のモンスーン開始日と特徵

\begin{tabular}{|c|c|c||c|c|c|}
\hline Year & \multicolumn{2}{|c|}{ Onset } & Year & \multicolumn{2}{|c|}{ Onset } \\
\hline \hline 1981 & $6 / 4$ & Non-Cyclone & 1992 & $6 / 16$ & Non-Cyclone \\
\hline 1982 & $6 / 7$ & Non-Cyclone & 1993 & $6 / 4$ & Non-Cyclone \\
\hline 1983 & $6 / 16$ & Cyclone & 1994 & $6 / 7$ & Cyclone \\
\hline 1984 & $6 / 1$ & Non-Cyclone & 1995 & $6 / 10$ & Non-Cyclone \\
\hline 1985 & $5 / 26$ & Non-Cyclone $※$ & 1996 & $6 / 10$ & Cyclone \\
\hline 1986 & $6 / 8$ & Cyclone & 1997 & $6 / 16$ & Non-Cyclone \\
\hline 1987 & $6 / 3$ & Cyclone & 1998 & $6 / 9$ & Cyclone \\
\hline 1988 & $6 / 4$ & Non-Cyclone & 1999 & $5 / 19$ & Cyclone \\
\hline 1989 & $5 / 29$ & Non-Cyclone & 2000 & $5 / 16$ & Non-Cyclone \\
\hline 1990 & $5 / 18$ & Cyclone & 2001 & $5 / 17$ & Non-Cyclone \\
\hline 1991 & $6 / 5$ & Cyclone & 2002 & $6 / 15$ & Non-Cyclone \\
\hline
\end{tabular}

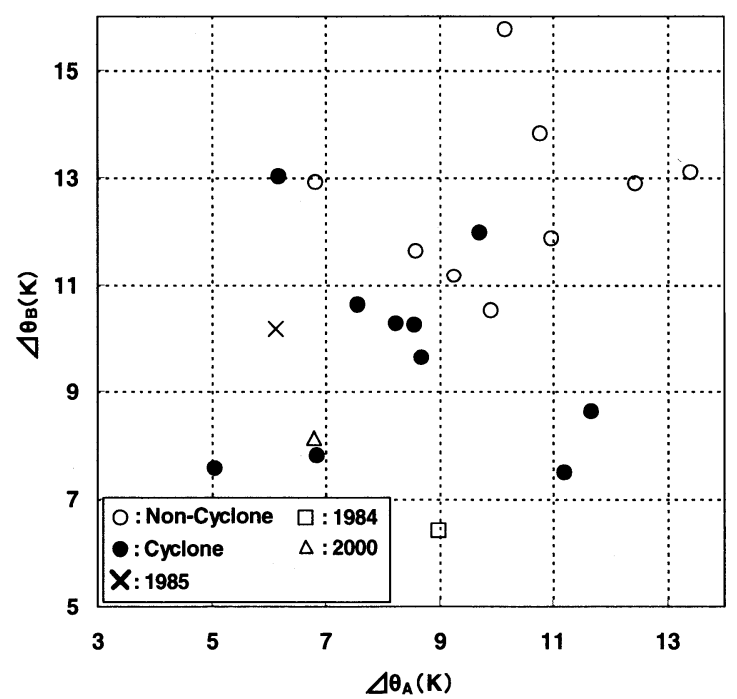

図-6 西風形成日の温度傾度.

\section{4. 年々変動}

3.の事例解析から夏季モンスーン期にインドに吹き 込む強い西風の形成過程は, サイクロンによってもたら される場合とそうではない場合があることがわかった. 1981年から2002年までについて西風形成までの季節変化 を調べ，それがサイクロンによってもたらされたものか を表-1にまとめる. なお, モンスーン開始は西風の形成 日とし, 東経60度-70度, 北緯10度-15度, 850hPaにおい て領域平均した風速が $9 \mathrm{~m} / \mathrm{s}$ より大きくなった日とし, 風 系のプロットとも比較して定義した。 また，本論文では サイクロンの定義の際に厳密な閾值を設定せず，ジオポ テンシャル高度において強い降水を伴う低気圧が存在し， その周囲に強い反時計回りの風系が形成されているもの をサイクロンとして視覚的に定義した．また，1981年か ら1996年までに関しては日平均降水量デー夕が利用でき ないためOLRによって激しい対流活動域と認められる領 域をサイクロンとした，サイクロンによって大気場に何 らかの変化が与えられ，西風が形成された場合を Cycloneとし，2001年のように徐々に場が形成されてい く場合をNon-Cycloneとした. 1985年はベンガル湾を北 
上する強いサイクロンによってアラビア海に西風が励起 され，そのままモンスーンの開始となった．イベントに よって西風が形成されたものだが，アラビア海周辺域や インド亜大陸を通るサイクロンによるものではないため ※をつけてNon-Cycloneとした。

22年の対象年のうち，9年がサイクロンによって西風 形成に至ったものである。サイクロンは急激な大気場の 変化をもたらすが, その発生時期や場所は年によって異 なる。一方, Non-Cyclone とした場合は2001年の季節進 行に共通する点が見出された，その季節進行を要約する と，インド亜大陸およびイラク-パキスタン領域の加熱 によって中東域からインド亜大陸の西岸に沿った北西風 が形成され，それによって運ばれる陸域の暖かい空気が アラビア海を暖める.アラビア半島の加熱が充分に進行 すると, アラビア海との間の温度傾度によってアフリカ 東部からアラビア海に吹き込む南西風が形成され，再び アラビア海の温位が低下する. アラビア半島とイランパキスタン領域の高温位域とアラビア海の低温位域との 間の温度傾度が大きくなることによって, アラビア海に 強い西風が形成される，すなわち，アラビア半島とアラ ビア海の温度傾度と中東域とアラビア海との温度傾度が 形成されることがモンスーンの西風形成に必要である. 図-6は，西風形成日における上記二つの温度傾度をプ ロットした物である。 $\Delta \theta_{\mathrm{A}}$ は中東域（東経60度-72.5度, 北緯25度-32.5度) とアラビア海（東経65度-72.5度, 北緯 5度-15度) との温位差, $\Delta \theta_{\mathrm{B}}$ はアラビア半島（東経45 度-55度, 北緯20度-30度）とアラビア海との温位差であ る. 白抜きでしめしたNon-Cycloneの場合には $\Delta \theta_{\mathrm{A}}, \Delta$ $\theta_{\mathrm{B}}$ ともに大きな值を示し, 西風形成期には陸域と海洋 との熱コントラストが大きくなっていることを示してい る。ただし，1984年㧍よび2000年に関しては，NonCycloneに関わらず温位差が小さい. 2000年はモンスー ン開始以前からインド亜大陸が広い範囲にわたって雲に 覆われており，そのためにインド西岸が高温位とならず， 周辺域の温位も上がらなかったために，アラビア半島等 との熱コントラストが形成されたのではないかと考えら れる. 1984年に関しては，温位差は小さいが温位分布は 他の年の西風形成期と同様に図-1bのようなパターンを 示しており, 他の年との明確な違いを示す特徵は認めら れなかった. 温位差が小さくても西風が形成するという 事実に関しては，今後の検討課題である.

Cycloneの場合の西風形成期における温位差はNonCycloneの場合に比べて小さい. すなわち，十分に温位 差が大きくなった状況では既に西風が形成されており， そこに至る過程でCycloneが発生するか否かが二つの西 風形成パターンを左右するものといえる。従って, 温位 差が十分でない時期にCycloneの発生・発達を予測する ことが, 西風形成すなわちインドモンスーン開始のパ ターンおよび開始時期の予測につながるといえる.

\section{5. 結論}

本研究では多様な地球環境データの統合活用のための 環境構築, 解析ツール群の作成を行い, 夏季インドモン スーン期に降水をもたらす西風の形成に着目して，大気 場の季節進行を記述した。一連の解析ツール群は, 現在 は問題発見型のツールであるが，将来的には気象現象の 物理法則の理解により資するものとして発展することが 期待される. 解析からは，1999年および2001年の比較か ら，サイクロンによって大気場の変化がもたらされる場 合と特別なイベントによらず徐々に西風か吹く場が形成 されるふたつの季節進行のパターンがあることがわかっ た. 徐々に場の形成が起こる場合には，西風形成期には アラビア半島とアラビア海拉よび中東域とアラビア海の 温位差が大きくなることが必要であることもわかった。

SSTが大気場に与える影響は，季節進行の中ではさほ ど大きくないが, 年ごとの基本的な場の形成には寄与し ており, 年々変動への影響は考慮しなければならない。

今後, 土䁃水分等の年々変動との関連や大規模循環場 との相互作用などに関する解析も行う必要がある。

謝辞：本研究では全球降水気候計画（GPCP）, NCEP/NCAR, 米国大気海洋庁（NOAA），国際衛星雲 気候計画 (ISCCP) とNASA TRMM Science Teamより提 供されたデータを用いた。ここに記し感謝の意を表す。

\section{参考文献}

1) Webster, P. J.,Magana, V. O, Palmer, T. N., Shukula, J., Thomas, R. A., Yanai, M. and Yasunari, T.: Monsoons:Process, predictability, and the prospects for prediction, J. Geophys.. Res., Vol.03, pp.451510, 1998.

2) Chelliah, M. and Arkin, P.: Large-scale variability of monthly longwave radiation anomalies over the global tropics, J. Climate, Vol.5, pp.371-389, 1992.

3) Liebmann, B. and Smith. C. A: Description of a Complete (Interpolated) Outgoing Longwave Radiation Dataset, Bull. Amer. Meteor. Soc., Vol.77, pp.1275-1277, 1996.

4) Kalney, E., Kanamitsu, M., Kistler, R., Collins, W., Deaven, D., Gandin,. L., Iredell, M., Saha, S., White, G., Woollen, J., Zhu, Y., Leet,aa, A., Reynolds, B., Chelliah, M., Ebisuzaki, W., Higgins, W., Janowiak, J., Mo, K. C., Ropelewski, C., Wang, J., Jenne, R., and Joseph, D.: NCEP/NCAR 40-years reanalysis project, Bull. Amer. Meteor. Soc., Vol.77, pp.437-472, 1997.

5) Schiffer, R.A., and Rossow, W.B.: The International Satellite Cloud Climatology Project (ISCCP): The first project of the World Climate Research Program, Bull. Amer. Meteor. Soc., Vol.64, pp.779-784, 1983.

(2003.9. 30受付) 